\title{
Advance directives: questionnaire survey of NHS trusts
}

\author{
Peter Diggory, Marion Judd
}

10 Campden Hill Square, London W8 7LB

Peter Diggory

retired gynaecologist

2 Torrington Gardens, London

N11 2AB

Marion Judd

coordinator

Correspondence to: M Judd

juddery@cwcom.net

BMJ 2000;320:24-5
An advance directive gives patients the legal right to give or withhold consent to specific medical treatments prospectively. This provides them with some reassurance about the dying process being managed in accordance with their wishes. Apprehension could be further allayed if it were known that the legal status of advance directives was consistently applied across the NHS.

Guidance on advance statements about medical treatment was initially published by the BMA in $1995 .{ }^{1}$ The legally binding status of advance directives was reiterated by Luttrell in $1996 .^{2}$ Nevertheless, in 1998 a survey of 214 general practitioners found that only $49 \%$ were aware that advance directives carry legal force. ${ }^{3}$ In 1999 the NHS Executive issued guidance on withholding consent to treatment ${ }^{4}$ and the General Medical Council issued guidance on the current legal position on advance directives. ${ }^{5}$ It remains unclear how NHS trusts have responded to this guidance and to what extent people can expect that their advance directive would be respected if they were an NHS patient who was dying.

We carried out a survey to discover what provision trusts have made to recognise advance directives through actual or intended development of policies.

\section{Methods and results}

We developed a questionnaire and sent it with a covering letter explaining the background and objectives of the study to chief executives or medical directors of 463 NHS trusts. We received responses from 247 (53\%) trusts (table)-for acute services (121), community services (55), and acute and community services combined (52); children (3); mental health and learning difficulties (9); and other services (7). Results showed that 37 trusts had already developed policies; 87 intended to or were in the process of doing so; 187 believed that national guidelines would be useful; 129 had requested illustrative copies of trust guidelines; and 70 did not intend to develop policies.

Most of the 37 trusts that had already developed a policy provided acute services; nine provided both acute and community services. Seventeen of these trusts provided their policies for analysis. Content analysis showed that the policies varied widely in approach, content, and consistency in understanding of the legal issues.

Of the 124 trusts that had developed or intended to develop policies, 98 provided acute services alone or combined acute and community services. Nearly one third of trusts that had already developed a policy provided information on how advance directives may be drawn up and guidance for any staff who feel unable to comply with their policy. One fifth of these advised patients to notify staff about their advance directive and provided legal guidance for staff.

Of the 70 trusts not intending to develop policies, 43 provided acute services, where a policy on advance directives is likely to be appropriate. Sixty three expressed interest in the development of national guidelines.

Altogether 187 trusts that responded believed that national guidelines on advance directives would be

\begin{tabular}{|c|c|c|c|c|}
\hline Trusts' replies & $\begin{array}{l}\text { Trusts that have } \\
\text { already developed a } \\
\text { policy }(\mathrm{n}=37)^{\star}\end{array}$ & $\begin{array}{c}\text { Trusts intending to } \\
\text { develop a policy } \\
(\mathrm{n}=87) \dagger\end{array}$ & $\begin{array}{l}\text { Trusts not intending to } \\
\text { develop a policy } \\
(\mathrm{n}=70) \ddagger\end{array}$ & $\begin{array}{c}\text { Other trusts } \\
(\mathrm{n}=53) \S\end{array}$ \\
\hline Believe national guidance would be useful & $32(86)$ & $83(95)$ & $63(90)$ & $9(17)$ \\
\hline $\begin{array}{l}\text { Make provision for patients to indicate in advance their unwillingness } \\
\text { to accept particular procedures or forms of treatment }\end{array}$ & $26(70)$ & $2(2)$ & 0 & 0 \\
\hline $\begin{array}{l}\text { When patients are admitted unconscious or otherwise unable to } \\
\text { communicate, provide guidance for staff on approaching relatives } \\
\text { or friends to ascertain whether advance directive already exists }\end{array}$ & $17(46)$ & $1(1)$ & 0 & 0 \\
\hline $\begin{array}{l}\text { If advance directive has not been drawn up, policies contain guidance } \\
\text { for clinicians on need to approach relatives or friends, or both, to } \\
\text { ascertain whether patient had expressed very definite views }\end{array}$ & $12(32)$ & $1(1)$ & $1(1)$ & 0 \\
\hline $\begin{array}{l}\text { Steps are taken to ensure that all relevant clinicians are aware of the } \\
\text { policy }\end{array}$ & $24(65)$ & $1(1)$ & 0 & 0 \\
\hline $\begin{array}{l}\text { Have developed guidance for staff who, for moral or ethical reasons, } \\
\text { feel unable to comply with the policy }\end{array}$ & $11(29)$ & 0 & 0 & 0 \\
\hline $\begin{array}{l}\text { Require that written information on making advance directives is } \\
\text { freely available to relevant patients, relatives, and carers }\end{array}$ & $5(13)$ & $1(1)$ & 0 & 0 \\
\hline $\begin{array}{l}\text { Require that a member of staff on each ward should have specific } \\
\text { responsibility for raising this issue with relevant patients }\end{array}$ & $2(5)$ & $1(1)$ & $1(1)$ & 0 \\
\hline $\begin{array}{l}\text { Require that patients should be routinely advised on admission that } \\
\text { advance directives may be discussed with ward staff }\end{array}$ & 0 & 0 & 0 & 0 \\
\hline Provide information on how advance directives may be drawn up & $11(29)$ & $1(1)$ & 0 & 0 \\
\hline Advise patients to notify staff of the existence of an advance directive & $8(21)$ & 0 & 0 & 0 \\
\hline $\begin{array}{l}\text { Provide specific guidance on legal and clinical effects of advance } \\
\text { directives on possible treatment under trust's care }\end{array}$ & $8(21)$ & $11(12)$ & $6(8)$ & 0 \\
\hline Requested illustrative copies of guidelines & $11(29)$ & $59(68)$ & $21(30)$ & $38(71)$ \\
\hline
\end{tabular}


useful. Only half, however, indicated that they were taking action.

\section{Comment}

Around one quarter of all NHS trusts, mainly those providing acute services, had developed or intended to develop policies on advance directives. Few trusts provided information and advice for patients about advance directives. None routinely advised patients that advance directives may be discussed with ward staff.

Requests for copies of specimen trust guidelines indicated a generally high level of interest, but the number of acute trusts with no plans or intention to develop their own policy is a matter for concern. Although only half the trusts that responded were currently taking action, three quarters were in favour of national guidelines, which suggests that more trusts would consider addressing the issue if national guidelines were available.

National guidelines should be developed to support a consistent approach to end of life care across the NHS for patients with advance directives.

We thank the medical directors, directors of nursing, and others who responded on behalf of their trusts; trusts that provided copies of their policies; and the East Yorkshire Community NHS Trust, which allowed its policy to be circulated as an illustrative example

Contributors: The paper was written jointly by both authors. MJ had the original idea for the study. The questionnaire was developed jointly by PD and MJ. PD collated the responses and $\mathrm{MJ}$ analysed the data. MJ is the guarantor for this paper.

Funding: No funding was obtained for the study. The Voluntary Euthanasia Society provided postage, paper, and help with distribution.

Competing interests: The authors are members of the Voluntary Euthanasia Society and Doctors for Assisted Dying.

1 British Medical Association. Advance statements about medical treatment. London: BMA, 1995

2 Luttrell S. Living wills do have legal effect provided certain criteria are met. BMJ 1996;313:1148.

3 Bowker L, Stewart K, Hayes S, Gill M. Do general practitioners know when living wills are legal? J $R$ Coll Physicians Lond 1998;32:351-3.

4 NHS Executive. Consent to treatment; summary of legal rulings. London: NHSE, 1999. ( Health service circular 1999/031.)

5 General Medical Council. Seeking patients'consent: the ethical considerations. London: GMC, 1999.

(Accepted 7 September 1999)

\section{My most unfortunate mistake Did I fail in my duty?}

Many years ago I retired, acquiring a swell marine house overlooking a busy harbour, and facing the sea. Below there was another group of houses where a man I will call Sam, and his wife, Clare, lived. I never knew them well, only meeting them on rare occasions down at the seafront. It was there one day that the accident occurred. My memory is evergreen. It was early morning. The sun was scorching; we were watching the ferry boat leaving the harbour. Suddenly there was the screeching sound of an engine. A car coming at high speed round a corner, from the opposite side of the road, was skidding towards us. My dog and I just escaped by jumping over a wall, while the car, smashing part of the wall, turned upside down. An ambulance was called. The driver of the car was Sam. He lay seemingly unconscious over his wheel, his dog by his side. Fearful of fire, I turned off the engine, and managed to extricate both occupants. The dog was no problem. Subdued, he quietly sat by mine. I always carried my stethoscope around, and both Sam's heartbeat and lungfields seemed normal, although his lips looked blue. There did not seem to be any obvious external injuries. I continued to speak quietly to him, and within a few minutes he regained consciousness, saying that the sun had obscured his vision, so he had lost control of his driving. The ambulance arrived, and then Sam's wife. I attempted to explain the situation to her, advising that the hospital casualty department would be best suited to Sam's needs; that a thorough medical examination was essential. Sam protested loudly; with his wife's help, he somehow managed to struggle to his feet. He obdurately refused to accept any help from the ambulance service and firmly refused my offer to contact his family doctor. Clare seemed subservient to his wishes. We watched them and their dog make their stumbling way back to their home. My later inquiries were obviously unwelcome. I considered at the time approaching the medical team at our local health centre, but decided that would betray patient confidentiality. Some months later, just listening to casual conversation, I learnt that Sam suffered from epilepsy and was on medication. He had also left his home, moved to another town, and was still driving a car. My dog and I had escaped. Would others? Why, I wondered, had I forgotten my training as a medical student and not considered epilepsy as one of the possible causes of unconsciousness; and if I had done so, would I then have at least have tried to contact Sam's family doctor? I still wonder. Had my obsession with patient confidentiality made me fail in my duty to the public?

We welcome articles of up to 600 words on topics such as A memorable patient, A paper that changed my practice, My most unfortunate mistake, or any other piece conveying instruction, pathos, or humour. If possible the article should be supplied on a disk. Permission is needed from the patient or a relative if an identifiable patient is referred to. We also welcome contributions for "Endpieces," consisting of quotations of up to 80 words (but most are considerably shorter) from any source, ancient or modern, which have appealed to the reader. 